\title{
Marketability of Sant Jordi Meat Corner
}

\author{
Dominique Marie L. Schulze \\ University of Negros Occidental-Recoletos, Bacolod City, Philippines \\ niksthesis67@gmail.com \\ https://orcid.org/0000-0001-8516-3156
}

\begin{abstract}
Sant Jordi Meat Corner (SJMC) is a charcuterie and specialty butcher meat shop in Bacolod City, Philippines. Using a descriptive research design, this study assessed the marketability of SJMC as a basis for a marketing plan. The data were gathered using a survey questionnaire that was answered by the owners and clients, competitor analysis chart, and store visits to SJMC's competitors. Available financial data of the company were also utilized to assess the financial position of the company. Utilizing descriptive statistics, the findings showed that products and price were rated highest, while promotion and process, and place were rated lowest. In the Competitive Profile Matrix, SJMC ranked third among the four meat shops. The financial analysis also showed that SJMC is profitable, liquid, and solvent. Thus, SJMC is marketable. It is recommended that SJMC may innovate its products and services, offering newer features or add-on services.
\end{abstract}

Keywords: Business Management, Marketability, Marketing Plan, Meat Industry, Meat Shop, Descriptive, Bacolod City, Philippines 